\title{
Essential Oil Composition of Clinopodium vulgare L. subsp. arundanum (Boiss.) Nyman from Bingöl (Turkey)
}

\author{
Ömer KILIÇ ${ }^{* 1}$, Mehmet Ali KUTLU ${ }^{2}$, Fethi Ahmet ÖZDEMİR ${ }^{3}$ \\ ${ }^{1}$ Bingol University, Technical Science Vocational College, Department of Park and Garden Plant, Bingol-Turkey \\ ${ }^{2}$ Beekeeping, Research, Development, Applications Centre Offices, Bingol University, Bingol-Turkey \\ ${ }^{3}$ Bingol University,Faculty of Science and Art, Department of Molecular Biology and Genetics, Bingol-Turkey
}

Received: 29 April 2017 - Revised: 07 June 2017 - Accepted: 23 June 2017

\begin{abstract}
Many of the medicinal and aromatic plants from Lamiaceae taxa are uses presumed to be connected to the terpenic constituents of the essential oils. In this study aerial parts essential oil of Clinopodium vulgare L. subsp. arundanum was analyzed by HS-SPME. As a result thirty seven components were identified. $\beta$ caryopyllene $(16.1 \%), \gamma$-terpinene $(15.4 \%)$, germacrene D $(10.3 \%), p$-cymene $(8.6 \%)$ and thymol $(6.4 \%)$ were detected the major constituents. With this study, chemotypes of studied sample were detected $\beta$-caryopyllene, $\gamma$ terpinene, germacrene D, $p$-cymene and thymol. In addition studied plant sample was found to be rich in respect to essential oils and the results discussed natural product, renewable resources and chemotaxonomy
\end{abstract}

Keywords: Clinopodium, essential oil, HS-SPME, Apiaceae

\section{INTRODUCTION}

Clinopodium vulgare $\mathrm{L}$. is one of the two Clinopodium spp. (Lamiaceae) growing wild in Anatolia. In Flora of Turkey, two subspecies are defined: vulgare and arundanum. The latter is widespread in Anatolia [1]. Until recently, essential oils have been studied most from the point of view their flavour and fragrance chemistry for flavouring foods, drinks and other goods. Actually, however, essential oils and their components are gaining increasing interest because of their relatively safe status, wide acceptance by consumers, and exploitation for potential multi-purpose functional uses [2]. Many authors, in fact, have reported antimicrobial, antifungal, antioxidant and radical-scavenging properties by spices and essential oils and, in some cases, a direct food-related application has been tested [3]. Clinopodium vulgare is one of the curative plants used in Turkish folk medicine, mainly during wars for the purposes of healing wounds; this plant also showed a very strong action on bacteria [4]. Aqueous extract of C. vulgare showed strong antitumor activity [5]. A literature survey has shown that there is one report on the volatile constituents of $C$. vulgare subsp. arundanum Boiss. growing in Turkey [6].

*Corresponding Author E-mail: omerkilic77@gmail.com

ISSN: 2148-6905 online /(C) 2017

DOI: $10.21448 /$ ijsm.356245 
In our study, essential oil composition of $C$. vulgare subsp. arundanum which was collected from Bingöl (Turkey) was undertaken for the first time.

\section{MATERIAL and METHODS}

\subsection{Plant Material}

C. vulgare subsp. arundanum was collected from Bingöl-Solhan, vicinity of Hazarşah village, dry slopes, 1700-1750 m, July 2015, O.Kilic. The taxonomic description of the plant sample was made according to volume 4 of Flora of Turkey [1]. Voucher specimen was deposited in the Bingöl University, Department of Park and Garden Plants.

\subsection{HS-SPME Procedure}

Dried aerial part powder of five grams plant samples were carried out by a head space solid phase microextraction method using a divinyl benzene/carboxen/polydimethylsiloxane fiber, with 50/30 um film thickness; before the analysis the fiber was conditioned in the injection port of the gas chromatography $(\mathrm{GC})$ as indicated by the manufacturer. For each sample, $5 \mathrm{~g}$ of plant samples, previously homogenized, were weighed into a $40 \mathrm{ml}$ vial; the vial was equipped with a "mininert" valve. The vial was kept at $35^{\circ} \mathrm{C}$ with continuous internal stirring and the sample was left to equilibratefor $30 \mathrm{~min}$; then, the SPME fiber was exposed for 40 min to the headspace while maintaining the sample at $35^{\circ} \mathrm{C}$. After sampling, the SPME fiber was introduced into the GC injector, and was left for $3 \mathrm{~min}$ to allow the analyzes thermal desorption. In order to optimize the technique, the effects of various parameters, such as sample volume, sample headspace volume, sample heating temperature and extraction time were studied on the extraction efficiency as previously reported by Verzera et al., [7].

\subsection{GC-MS Analysis}

A Varian 3800 gas chromatograph directly inter faced with a Varian 2000 ion trap mass spectrometer was used with injector temperature, $260^{\circ} \mathrm{C}$; injection mode, splitless; column, 60 $\mathrm{m}$, CP-Wax $52 \mathrm{CB} 0.25 \mathrm{~mm}$ i.d., $0.25 \mathrm{~mm}$ film thickness. The oven temperature was programmed as follows: $45^{\circ} \mathrm{C}$ held for $5 \mathrm{~min}$, then increased to $80^{\circ} \mathrm{C}$ at a rate of $10^{\circ} \mathrm{C} / \mathrm{min}$, and to $240^{\circ} \mathrm{C}$. at $2^{\circ} \mathrm{C} / \mathrm{min}$. The carrier gas was helium, used at a constant pressure of $10 \mathrm{psi}$; the transfer line temperature, $250^{\circ} \mathrm{C}$; the ionisation mode, electron impact (EI); acquisit ion range, 40 to $200 \mathrm{~m} / \mathrm{z}$; scan rate, $1 \mathrm{us}^{-1}$. The compounds were identified using the NIST library, mass spectral library and verified by the retention indices which were calculated as described by Van den Dool and Kratz [8]. The relative amounts were calculated on the basis of peak-area ratios. The identified constituents of $C$. vulgare subsp. arundanum is listed in Table 1.

Table 1. Essential oil composition of Clinopodium vulgare subsp. arundanum (\%)

\begin{tabular}{ccc}
\hline Compounds & RRI* $^{*}$ & $\%$ \\
\hline$\alpha$-thujene & 1016 & 1.5 \\
$\alpha$-pinene & 1022 & 0.8 \\
Camphene & 1034 & 0.4 \\
Sabinene & 1052 & 0.1 \\
$\beta$-pinene & 1056 & 2.1 \\
$\beta$-mrycene & 1064 & 2.5 \\
$\alpha$-terpinene & 1085 & 1.8 \\
\hline
\end{tabular}




\begin{tabular}{|c|c|c|}
\hline$\alpha$-phelladrene & 1090 & 2.2 \\
\hline Limonene & 1096 & 0.1 \\
\hline$p$-cymene & 1098 & 8.6 \\
\hline$\beta$-ocimene & 1100 & 0.2 \\
\hline 1,3,6- octatriene & 1108 & 0.1 \\
\hline$\gamma$-terpinene & 1117 & 15.4 \\
\hline Trans-sabinene hydrate & 1126 & 0.1 \\
\hline Linalool & 1148 & 0.2 \\
\hline Terpineol-4-ol & 1166 & 0.4 \\
\hline Camphor & 1182 & 0.1 \\
\hline Borneol & 1200 & 1.3 \\
\hline Pulegone & 1205 & 0.1 \\
\hline$\alpha$-terpinolene & 1220 & 2.5 \\
\hline Thymol & 1295 & 6.4 \\
\hline Carvacrol & 1300 & 3.3 \\
\hline$\alpha$-copaene & 1350 & 0.2 \\
\hline$\beta$-Caryophyllene & 1382 & 16.1 \\
\hline$\beta$-cubebene & 1400 & 0.3 \\
\hline Aromadendrene & 1406 & 0.1 \\
\hline$\alpha$-humulene & 1418 & 3.4 \\
\hline Germacrene D & 1435 & 10.3 \\
\hline Piperitenone & 1441 & 1.2 \\
\hline$\beta$-bisabolene & 1450 & 0.6 \\
\hline Bicyclogermacrene & 1455 & 0.1 \\
\hline$\delta$-cadinene & 1462 & 0.1 \\
\hline Spathulenol & 1495 & 0.2 \\
\hline Caryophyllene oxide & 1497 & 4.1 \\
\hline$\alpha$-muurolene & 1520 & 1.1 \\
\hline Spathulenol & 1620 & 0.1 \\
\hline Hexadecanoic acide & 1702 & 0.4 \\
\hline RRI*: Relative Retention Index & Total & 88.5 \\
\hline
\end{tabular}




\section{RESULTS and DISCUSSIONS}

In this study, $\beta$-caryopyllene (16.1\%), $\gamma$-terpinene $(15.4 \%)$, germacrene $\mathrm{D}(10.3 \%)$, $\mathrm{p}$ cymene $(8.6 \%)$ and thymol $(6.4 \%)$ were detected the major constituents of the essential oil plant. In a study was designed to examine the chemical composition essential oil of Clinopodium vulgare by GC-MS analysis of the oil resulted in the identification of 40 compounds, representing $99.4 \%$ of the oil; thymol (38.9\%), $\gamma$-terpinene $(29.6 \%)$ and $p$-cymene (9.1\%) were the main components [9]; similarly in our study $\gamma$-terpinene (15.4\%), thymol $(16.4 \%)$, p-cymene $(8.6 \%)$ and thymol $(6.4 \%)$ were detected high percentages (Table 1$)$.

In another research, a total of 34 components of the essential oil of Clinopodium gracile were identified and principal compounds of the essential oil were germacrene D (20.59\%), nootkatone $(8.22 \%)$, morillol $(7.74 \%), \beta$-elemene $(7.38 \%), \alpha$-bergamotene $(6.08 \%)$, cis- $\beta$ farnesene $(5.47 \%)$ and caryophyllene $(5.17 \%)$ [10]. It is noteworthy that, nootkatone and morillol were not detected in the essential oil of C. vulgare subsp. arundanum (Table 1). In another investigation, $C$. vulgare contains piperitone oxide (11.4\%) [11]; this compound was not found in the oil of $C$. vulgare subsp. arundanum as main component (Table 1).

The differences in chemical composition of oil of present study and previous research may be because of the collection time, chemotypes, drying conditions, mode of distillation, geographic and climatic factors. The essential oil composition of C. vulgare subsp. arundanum collected from two different localities in Turkey, was analysed by means of GC and GC-MS; thirtyseven compounds were identifed, representing 89.6-90.5\% of the samples; and the main constituents of the oils were germacrene-D, $\beta$-caryophyllene and $\beta$-caryophyllene oxide [6]. Germacrene-D and $\beta$-caryophyllene also were found to be the main constituents of studied sample (Table 1).

\section{CONCLUSION}

In conclusion, the present work is the first report on the composition of essential oils obtained from the aerial parts of $C$. vulgare subsp. arundanum from Bingöl (Turkey). Sample extracts from C. vulgare subsp. arundanum was rich in essential oil compounds. The biologic activity of Clinopodium taxa may be related to its richness in secondary metabolites, especially essential oils. $\beta$-caryopyllene, $\gamma$-terpinene, germacrene $\mathrm{D}, \mathrm{p}$-cymene and thymol were found to be the reason of chemotypes of $C$. vulgare subsp. arundanum.

\section{Acknowledgement}

The authors acknowledge the Scientific and Research Council of Bingol University (BAP TBMYO.2016.00.001) for support this study.

\section{Conflict of Interests}

Authors declare that there is no conflict of interests.

\section{REFERENCES}

[1]. Davis, P.H. (1982). Flora of Turkey and East Aegean Islands. Edinburgh, University Press, 7.

[2]. Ormancey, X., Sisalli, S., \& Coutiere, P. (2001). Formulation of essential oils in functional parfumery. Parfums Cosmetiques Actualites, 157, 30-40

[3]. Madsen, H.L., \& Bertelsen, G. (1995). Spices as antioxidants. Food Science and Technology, 6, 271-277.

[4]. Opalchenova, G., \& Obreshkova, D. (1999). Antibacterial Action of Extracts of Clinopodium vulgare L. Curative Plant. Drug Dev Indian Pharmachy, 25, 323-328. 
[5]. Dzhambazov, B., Daskalova, S., Monteva, A., \& Popov, N. (2002). In vitro Screening for Antitumour Activity of Clinopodium vulgare L. (Lamiaceae). Extracts Biological Pharmachy Bulletin, 25, 499-504.

[6]. Kökdil, G. (1998). Composition of the Essential Oil of Clinopodium vulgare L. spp. arundanum (Boiss.) Nyman Collected From Two Different Localities in Turkey. Flavour and Fragrance Journal, 13, 170-172.

[7]. Verzera, A., Zıno, M., Condurso, C., Romeo, V., \& Zappala, M. (2004). Solid-phase microextraction and gas chromatography/mass spectrometry for the rapid characterisation of semi-hard cheeses. Analitic Bioanalitical Chemistry, 380, 930-936.

[8]. Van Den Dool, H., \& Kratz, P.D. (1963). A generalization of the retention index system including linear temperature programmed gas-liquid partition chromatography. Journal Chromatography, 11, 463-471.

[9]. Tepe, B., Sihoglu-Tepe, A., Daferer, D., Moschos, P., \& Sokmen A. (2007). Chemical composition and antioxidant activity of the essential oil of Clinopodium vulgare L. Food Chemistry, 103(3), 766-770.

[10]. Chen, X.B., Liu, X.C., Zhou, L., \& Liu, Z.L. (2013). Essential Oil Composition and Larvicidal Activity of Clinopodium gracile (Benth)Matsum Aerial Parts against the Aedes albopictus Mosquito. Tropical Journal of Pharmaceutical Research, 12 (5), 799-804.

[11]. De Pooter, H.L., \& Schamp, N.M. 1986. Progress in Essential Oil Research, ed. E. J. Brunke, p. 139, Walter de Gruyter, New York. 